\title{
Peach Tree Growth as Influenced by Grass Species Used in a Killed-sod Planting System
}

\author{
W.V. Welker ${ }^{1}$ and D.M. Glenn ${ }^{2}$ \\ Appalachian Fruit Research Station, Agricultural Research Service, U.S. \\ Department of Agriculture, Kearneysville, WV 25430
}

Additional index words. orchard soil management, Prunus persica

\begin{abstract}
Peach [Prunus persica (L.) Batsch] trees were planted in killed sod developed from five different grasses. Tree growth was evaluated within the killed-sod treatments, as well as between killed-sod and bare soil treatments. Canopy width, tree height, and trunk cross-sectional area were all greater in the killed-sod treatments than in the bare soil treatments. All five grasses tested were acceptable for developing a killed-sod mulch. Chemical names used: $\mathrm{N}$-(phosphonomethyl) glycine (glyphosate); $\mathbf{N}^{1}(3,4-d i-$ chlorophenyl)-N,N-dimethylurea (diuron); 5-chloro-3-(1-1-dimethylethyl)-6-methyl2,4(1H,3H)-pyrimidinedione (terbacil).
\end{abstract}

The traditional method of soil preparation for planting fruit trees has been to plow and cultivate the soil to provide a vegetation-free area. This type of soil management results in unprotected soil and potential soil erosion (Ghadiri and Payne, 1986). Erosion losses can be excessive under certain rainfall and topographic conditions. In previous studies (Glenn and Welker, 1989a, 1989b; Welker and Glenn, 1988), establishing a living sod and then killing the sod with herbicides and planting peach trees in the undisturbed killed sod, resulted in greater tree growth and fruit yield than the conventional method. The killed-sod system retarded the depletion of organic matter and increased water infiltration rates, aggregate stability, and macroporosity, while reducing rainfall runoff. 'Kentucky 31' (K-31), tall fescue (Festuca arundinacea Schreb. ) was used in those studies. The objective of this study was to evaluate additional grass species in a killedsod management system to determine whether $\mathrm{K}-31$ was unique in its ability to influence peach tree growth when used to develop a killed-sod mulch.

Five grasses were seeded in Spring 1982. They were K-31, 'Falcon' fescue (Festuca arundinacea Schreb.), orchardgrass (Dactylis glomerata L.), perennial ryegrass ( $\mathrm{Lo}$ lium perenne L.), and Kentucky bluegrass (Pea pratensis L.). Each plot was $2.5 \mathrm{~m}$ wide and $14 \mathrm{~m}$ long. A 2.5 -m-wide area of K-31 between plot rows was maintained with periodic mowing. Two bare soil plots were included and maintained weed-free with

Received for publication 20 July 1989. The cost of publishing this paper was defrayed in part by the payment of page charges. Under postal regulations, this paper therefore must be hereby marked advertisement solely to indicate this fact.

${ }^{\mathrm{I}}$ Weed Scientist.

${ }^{2}$ Soil Scientist. cultivation until 1985, when they were tilled to a depth of $15 \mathrm{~cm}$ before planting. A randomized complete-block design with five replications was used. The soil type was a Hagerstown silt loam (fine, mixed mesic Typic Hapludalf)

In Spring 1985, the grass plots were treated with glyphosate at $2.2 \mathrm{~kg}$ a.e./ha to kill the grass. Two weeks after the grass plots were sprayed, uniform-sized (10 $\mathrm{mm}$ in diameter) 'Redhaven' on Halford seedling rootstock were planted in hand-dug holes. The trees were planted $3.5 \mathrm{~m}$ apart in rows spaced 5 $\mathrm{m}$ apart. Each plot contained three trees, with a guard tree between plots in the row. Trees were initially headed back to a height of $1 \mathrm{~m}$.

Two weeks after the trees were planted, a residual herbicide treatment of diuron plus terbacil, each at $1.12 \mathrm{~kg}$ a.i./ha, was applied as a tank mix to all the grass plots and one of the bare soil plots. This same herbicide treatment was applied each spring to maintain those plots weed-free. The second bare soil plot was maintained weed-free with cultivation and hand hoeing. The trees were trained to an open-center system and were pruned accordingly each spring. No fertilizer or irrigation was applied during the study. Measurements of canopy width, tree height, and trunk circumference were made at the end of each growing season. Trunk circumference was measured $30 \mathrm{~cm}$ from ground level and was used to calculate trunk, crosssectional area (TCA). Nitrogen was measured in fully expanded, midshoot leaves collected in late July each year. Each sample consisted of 15 leaves per tree from each of three trees per plot. Leaves were washed in deionized water, dried at $60 \mathrm{C}$, and ground to pass through a 40-mesh screen. Leaf $\mathrm{N}$ content was determined in a 100-mg sample using the Kjeldahl digestion and titration method (Horowitz, 1970). No yield data were obtained due to freeze damage of flower buds.
Table 1. Effect of soil management and grass species used in a killed-sod planting system on canopy width of young peach trees.

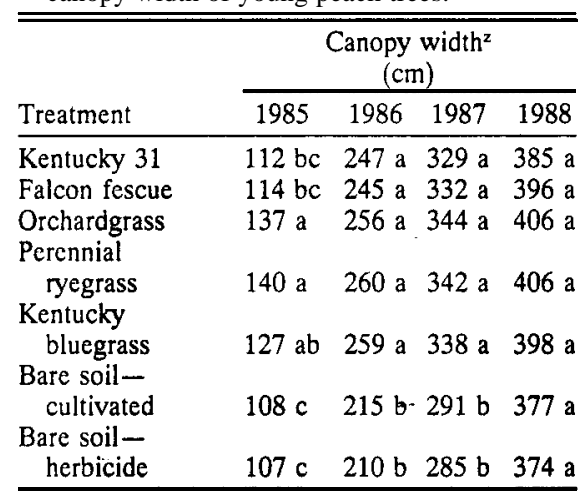

${ }^{2}$ Mean separation within columns by Duncan's multiple range test $(P=0.05, \mathrm{n}=15)$.

Table 2. Effect of soil management and grass species used in a killed-sod planting system on tree height of young peach trees.

\begin{tabular}{lcccc}
\hline \hline & \multicolumn{4}{c}{$\begin{array}{c}\text { Tree } \mathrm{ht}^{\mathrm{z}} \\
\text { (cm) }\end{array}$} \\
\cline { 2 - 5 } Treatment & 1985 & 1986 & 1987 & 1988 \\
\hline Kentucky 31 & $175 \mathrm{c}$ & $277 \mathrm{a}$ & $315 \mathrm{ab}$ & $312 \mathrm{a}$ \\
$\begin{array}{c}\text { Falcon fescuc } \\
\text { Orchardgrass }\end{array}$ & $173 \mathrm{c}$ & $282 \mathrm{a}$ & $328 \mathrm{a}$ & $319 \mathrm{a}$ \\
$\begin{array}{c}\text { Perennial } \\
\text { ryegrass }\end{array}$ & $205 \mathrm{a}$ & $287 \mathrm{a}$ & $327 \mathrm{a}$ & $326 \mathrm{a}$ \\
$\begin{array}{c}\text { Kentucky } \\
\text { bluegrass }\end{array}$ & $184 \mathrm{bc}$ & $281 \mathrm{a}$ & $322 \mathrm{ab}$ & $324 \mathrm{a}$ \\
$\begin{array}{c}\text { Bare soil- } \\
\text { cultivated }\end{array}$ & $184 \mathrm{bc}$ & $252 \mathrm{~b}$ & $305 \mathrm{bc}$ & $314 \mathrm{a}$ \\
$\begin{array}{c}\text { Bare soil- } \\
\text { herbicide }\end{array}$ & $176 \mathrm{c}$ & $237 \mathrm{~b}$ & $293 \mathrm{c}$ & $312 \mathrm{a}$ \\
\hline
\end{tabular}

${ }^{2}$ Mean separation within columns by Duncan's multiple range test $(P=0.05, \mathrm{n}=15)$.

Duncan's multiple range test was used as the mean separation test when significant treatment effects were identified by analysis of variance.

There were significant differences in the canopy width of peach trees among grass species in the first year (Table 1). Trees grew best in the killed-sod treatments developed from orchardgrass and perennial ryegrass, whereas trees grew least in K-31 and 'Falcon' fescue. There were no statistical differences in canopy width among grass species treatments after the first year. Trees grown in killed sod of perennial ryegrass and orchardgrass were significantly taller than those grown in K-31 and 'Falcon' fescue in the first year (Table 2). There was no statistical difference in tree height among grass species after the first year. This change was partially due to the annual pruning associated with the training system used. The TCA of trees grown in perennial ryegrass was greater than that of trees grown in K-31, 'Falcon' fescue, and Kentucky bluegrass in the first growing season (Table 3). There were no statistical differences in TCA among grass species after the first year. The killed-sod treatments all 
Table 3. Effect of soil management and grass species used in a killed-sod planting system on trunk cross-sectional area of young peach trees.

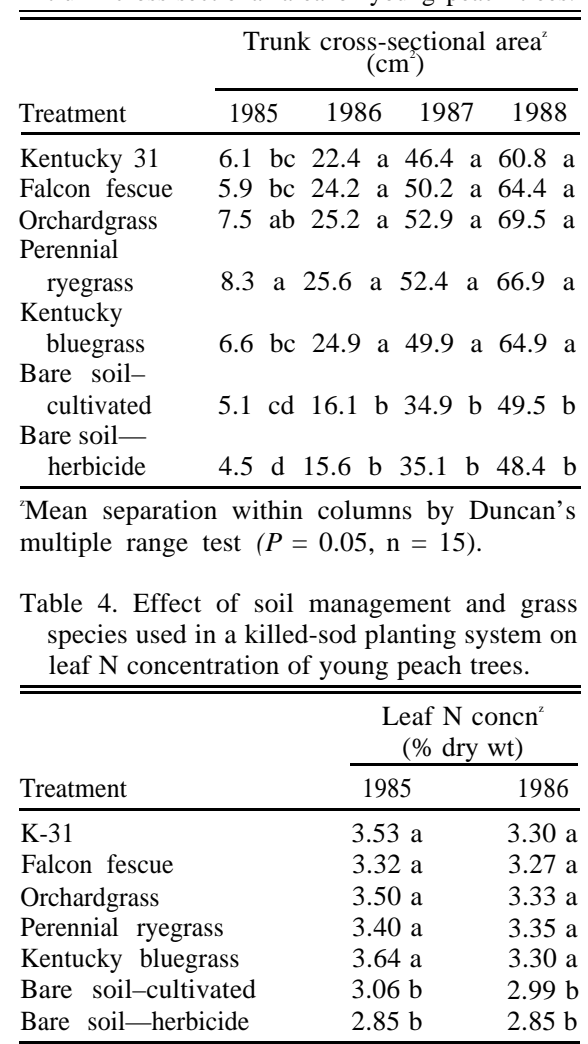

'Mean separation within columns by Duncan's multiple range test $(P=0.05, \mathrm{n}=15)$.

resulted in greater growth than the bare soil treatments through the third growing season.

It was not until the 4th year that the canopy width and tree height of those trees raised in bare soil equaled those raised in killed sod. TCA of trees grown in killed sod was greater at the end of 4 years than the TCA of trees grown in the bare soil treatments.

Leaf $\mathrm{N}$ levels were significantly higher during the first and second growing seasons in all the killed-sod treatments than in the bare soil treatments (Table 4). There were no differences between management systems after the second growing season (range 2.632.76 in 1987 and 3.21-3.44 in 1988). These results are similar to those in our previous studies with killed sod (Welker and Glenn, 1988). There were no differences in leaf $\mathrm{N}$ content among grass species treatments.

$\mathrm{K}-31$ was used exclusively in our previous studies (Glenn and Welker, 1989a, 1989b; Welker and Glenn, 1988) investigating the attributes of a killed-sod planting system. This study showed that K-31 was not unique in its ability to improve peach tree growth when used to develop a killed-sod mulch. All of the grasses used in this study resulted in greater growth of the young peach trees than the conventional bare soil system, although $\mathrm{K}-31$ resulted in the least growth response of the grasses tested.

\section{Literature Cited}

Ghadiri, H. and D. Payne. 1986. The risk of leaving the soil surface unprotected against falling rain. Soil and Tillage Res. 8:119-130.
Glenn, D.M. and W.V. Welker. 1989a. Orchard soil management systems influence rainfall infiltration. J. Amer. Soc. Hort. Sci. 114:10-14. Glenn, D.M. and W.V. Welker. 1989b. Cultural practices for enhanced growth of young peach trees. Amer. J. of Alternative Agr. 4:8-11.

Horowitz, W. (cd.). 1970. Official methods of analysis. 11th ed. Assn. Offic. Chem., Washington, D.C. p. 17-18

Welker, W.V. and D.M. Glenn. 1988. Growth response of young peach trees and changes in soil characteristics with sod and conventional planting systems. J. Amer. Soc. Hort. Sci. 113:652-656.

HORTSCIENCE 25(5):515-516. 1990.

\title{
Influence of Aluminum and Manganese on Rabbiteye Blueberries
}

\author{
James M. Spiers \\ U.S. Department of Agriculture, Agricultural Research Station, Small \\ Fruit Research Station, Poplarville, MS 39470
}

Additional index words. plant nutrition, Vaccinium ashei

Abstract. A sand culture study arranged in a $3 \times 3$ factorial was used to determine the influence of $\mathrm{Al}$ and $\mathrm{Mn}$ levels on leaf nutrient content and plant growth of 'Tifblue' rabbiteye blueberry (Vaccinium ashei Reade). Aluminum fertilization increased leaf Al content but did not affect plant vigor, leaf dry weight, or chlorosis. Manganese fertilization resulted in increased $\mathrm{Mn}$ in the leaves and a decrease in all growth parameters measured. The Al $\times$ Mn interactions were significant for Mn concentration in the leaves and vigor ratings. At the highest $\mathrm{Mn}$ fertilization rate, increasing $\mathrm{Al}$ fertilization had a synergistic influence on leaf Mn. Plant vigor at the highest Mn rate was lowest when no Al fertilizer was added. Increasing Al fertilization resulted in better plant vigor in plants grown with a high rate of Mn fertilization.

Rabbiteye blueberries are acidophilic plants that can accumulate high levels of $\mathrm{Mn}$ and Al (Korcak, 1988; Spiers, 1984). In field conditions, leaf levels of $\mathrm{Al}$ and $\mathrm{Mn}$ in $V$. angustifolium Ait. and V. myrtilloides Michx. were up to 110 and $1500 \mathrm{mg} \cdot \mathrm{kg}{ }^{-1}$ respectively (Trevett et al., 1968). Field-grown highbush blueberries (V. corymbosum L.) had high levels of leaf $\mathrm{Al}\left(445 \mathrm{mg} \cdot \mathrm{kg}^{-1}\right)$ and $\mathrm{Mn}$ (183 $\mathrm{mg} \cdot \mathrm{kg}^{-1}$ ) (Ballinger and Goldston, 1967). There was no evidence of reduced growth at these $\mathrm{Al}$ and $\mathrm{Mn}$ levels.

Aluminum in large amounts is toxic to plants and any stimulator effects of $\mathrm{Al}$ on the growth of Vaccinium and other calcifugous plants may be due to indirect effects associated with lowering soil $\mathrm{pH}$ (Pratt, 1973). Peterson et al. (1987) indicated high leaf Al levels (up to $317 \mathrm{mg} \cdot \mathrm{kg}^{-1}$ ) associated with aluminum sulfate fertilization may cause poor growth in rabbiteye blueberries. Excess Al and $\mathrm{Mn}$ induced visible $\mathrm{Mg}$ deficiency and reduced leaf $\mathrm{Mg}$ and $\mathrm{Ca}$ in norway spruce (Picea abies L.) seedlings (Hecht-Buchholz et al., 1987); however, no visible toxicity symptoms were observed in several blueberry species treated with high levels of $\mathrm{Al}$ and Mn (Korcak, 1988). In the same study, 'Tifblue' rabbiteye blueberry exhibited less growth under high $(1.7 \mathrm{mM}) \mathrm{Mn}$ and best growth with intermediate $(0.072 \mathrm{mM}) \mathrm{Mn}$ fertilization. The objective of this study was

Received for publication 30 Mar. 1989. The cost of publishing this paper was defrayed in part by the payment of page charges. Under postal regulations, this paper therefore must be hereby marked advertisement solely to indicate this fact. to determine main and interactive effects of $\mathrm{Al}$ and Mn fertilization on 'Tifblue' rabbiteye blueberry.

Two-year-old 'Tifblue' plants were potted in 1 1-liter containers of water-washed sand during February 1987. This study was conducted in a fiberglass shade house (20\% shade) under natural daylength and temperatures. Plants were grown for 1 month without fertilization, then from 15 Mar. until 15 May were fertilized uniformly with a complete nutrient solution and then pruned to a height of $\approx 10 \mathrm{~cm}$.

Beginning 15 June 1987, previously described nutrient solutions (Spiers, 1978) with differential $\mathrm{Al}$ and $\mathrm{Mn}$ concentrations were applied to the pots 5 days a week. Nitrogen was supplied as $\left(\mathrm{NH}_{4}\right)_{2} \mathrm{SO}_{4}$ and solution $\mathrm{pH}$ was adjusted to $5.5 \pm 0.2$ with $\mathrm{H}_{2} \mathrm{SO}_{4}$. All pots were leached with tap water followed by demineralized water twice weekly. Fertilizer treatments were: all combinations of $\mathrm{Al}(0,3.7$, and $37 \mathrm{mM})$ and $\mathrm{Mn}$ levels $(0$, 1.8 , and $18 \mathrm{mM})$ supplied as $\mathrm{Al}(\mathrm{OH})_{3}$ and $\mathrm{MnCl}_{4} \mathrm{H}_{2} \mathrm{O}$, respectively. The 3 x 3 factorial experiment was arranged in a randomized complete-block design with single plants as experimental units and five replications. On 23 Sept. 1987, plants were visually rated for vigor $(0=$ dead, $5=$ most vigorous $)$ and chlorosis $(1=$ most chlorosis, $5=$ no symptoms). Leaf numbers 4,5 , and 6 from the terminal of several branches were collected, dried $(60 \mathrm{C})$, finely ground, and analyzed by atomic absorption spectrophotometry (Mn) or colorimetry (Al) (Chapman and Pratt, 1978). Total growth (dry-weight basis) was determined by harvesting the new growth 